Egyptian Journal of Aquatic Biology \& Fisheries

Zoology Department, Faculty of Science,

Ain Shams University, Cairo, Egypt.

ISSN $1110-6131$

Vol. 23(2): 109 - 121 (2019)

www.ejabf.journals.ekb.eg

\title{
Remediation of toxic effect of Mercuric Chloride on the Nile Tilapia, Oreochromis niloticus using Selenium
}

\author{
Fatma A. El-Matary ${ }^{1}$, Mokhtar S. Beheary ${ }^{2 *}$, Rania O. Barakat ${ }^{1}$ and \\ Abd El-Hakim A. Elgamal ${ }^{1}$ \\ 1- National Institute of Oceanography and Fisheries, Egypt. \\ 2- Environmental Science Department, Faculty of Sciences, Port Said University, Egypt. \\ *Corresponding author: beheary@ hotmail.com
}

\section{ARTICLE INFO \\ Article History: \\ Received: Jan. 18, 2019 \\ Accepted: March 28, 2019 \\ Online: April 2019}

Keywords:

Remediation

Selenium

Mercury

Haematology

Histopathology

Oreochromis niloticus

\begin{abstract}
The present results showed that heavy metals $\left(\mathrm{HgCl}_{2}\right)$ have affected the biological parameters of Oreochromis niloticus. These effects depended on the duration of the exposure and the concentration of the heavy metal used. The effect of various doses level of $\mathrm{HgCl}_{2}$ on the erythrocyte count (Red blood cells) decreased under the effect of the high doses of $\mathrm{HgCl}_{2}(0.08 \mathrm{mg} / \mathrm{l}$ or more). A significance difference was recorded in comparison with the control fish $(\mathrm{p}<0.05)$.The total white blood cells counts significantly increased as the concentration of $\mathrm{HgCl}_{2}$ increase when compared to the control fish. In contrast, hemoglobin $(\mathrm{Hb})$ levels significantly $(\mathrm{p}<0.05)$ decreased after the fish exposed to high level doses of $\mathrm{HgCl}_{2}$. Addition of selenium $\left(\mathrm{Na}_{2} \mathrm{SeO}_{3}\right)$ at doses of 1.0 and $2.0 \mathrm{mg} / \mathrm{kg}$ to fish food for a period of 20 days of treatment with $\mathrm{HgCl}_{2}$ improved blood constituent. Treated gills with high doses of $\mathrm{HgCl}_{2}$ showed alteration on both of primary and secondary lamellae and an increase in the mucous secretion when compared with the control tissue. No abnormalities occurred in the liver of control fish. The main alterations in the liver of fish were observed after treatment with high doses level of $\mathrm{HgCl}_{2}(0.06-0.08 \mathrm{mg} / \mathrm{l})$. The hepatocytes were hypertrophied and the nuclei showed necrosis.
\end{abstract}

\section{INTRODUCTION}

Mercury is considered as one of the most dangerous toxic heavy metals, especially in the aquatic environment (Asefi and Zamani, 2015). Mercuric chloride increases $\mathrm{Hg}$ deposition in the aquatic environments and results from the increased anthropogenic activities, enhancing bioaccumulation of $\mathrm{Hg}$ in the food chain and higher $\mathrm{Hg}$ concentration in fish (Jones et al., 2013). The typical concentration of $\mathrm{Hg}$ in edible tissues of various species of fish ranges from 50 to $1,400 \mu \mathrm{g} / \mathrm{kg}$ (IPCS, 2003). Nijmi and Kisson (1994) reported that the level could be reached to $20 \mathrm{mg} / \mathrm{kg}$ which may cause toxicity in fish. Kruzikova et al., (2008) confirmed that $\mathrm{Hg}$ can be predominantly deposited as $\mathrm{MeHg}$ in fish tissue. However, Ikingura and Akagi (2003) postulated that a substantive level of $\mathrm{Hg}(0$ to $44 \%$ ) can also be present as inorganic $\mathrm{Hg}$ in fish especially in seafood (Moon et al., 2011). Mercury exposure to fish at high level inorganic or organic from can permanently damage the brain, kidney (ATSDR, 2003). 
However, most researchers do not give enough attention to nutritional factors that might influence organisms in response to heavy metal intoxication (Shapman and Chan, 2000).

Fish considered as a well - balanced diet because of its nutritional benefits such as high quality of protein, vitamins, high energy and minerals (Pieniak et al., 2010). In addition, fish are rich sources of omega-3 and they contain a very low level of cholesterol (Groth, 2010; Vieira, 2011). In human, fish help in neural tissue development of children and have an active role in coronary heart disease (Swanson et al., 2012). In contrast, fish can also be a potential source of toxic metals at a higher trophic level through their consumption (Wang et al., 2012).

The Nile tilapia was selected as the test organism in the present study for its great aquaculture and commercial value. Tilapia is the third most important cultured fish group in the world. In Egypt, the aquaculture tilapia production (38\%) is the highest (GAFRD, 2001; Beheary et al., 2015). In the last few decades, fish exposure to heavy metals presents unique problems from both toxicological and nutritional perspectives (Clarkson, 1998; Moniruzzaman et al., 2017; Beheary and El-Matary, 2018).

To reduce the problem that results from the effect of heavy metal $\mathrm{HgCl}_{2}$, Selenium $\left(\mathrm{Na}_{2} \mathrm{SeO}_{3}\right)$ is a necessary micronutrient has been shown to interact with $\mathrm{Hg}$ in a variety of organisms (Truong et al., 2014). Hg- Se interaction has commonly been described as antagonistic due to the protective effect of $\mathrm{Se}$ on $\mathrm{Hg}$ toxicity (Yang et al., 2008; Bjork Lund et al., 2017). However, synergistic effects have also been reported by Lemire et al., (2010) and Penglase et al., (2014). This in consistent phenomenon may be caused by the differences in species, dosing concentration, and administration methods (Wyatt et al., 2016; Wang and Wang, 2017). The aim of the present work is to study the effect of sub-lethal doses of mercuric chloride on haematology parameters and Histopathological changes on liver and gills. As well as using selenium (sodium selenite, $\mathrm{Na}_{2} \mathrm{SeO}_{3}$ ) to assess the detoxify of $\mathrm{HgCl}_{2}$ impacts.

\section{MATERIALS AND METHODS}

\section{Fish collection:}

The experiment was carried out at El-Serw station for fish researches, Damietta governorate, which belong to National Institute of Oceanography and Fisheries, Egypt. The fish were collected carefully to avoid any injury occurs and treated with $0.1 \% \mathrm{KMnO}_{4}$ solution for about few minutes for removal any fungal infection.

In August 2017, a total number of 300 fish collected in a live state with total body weighs ranged from 60-80 gm were grouped together in a holding tank of $1000 \mathrm{~L}$ capacity filled with de-chlorinated water for a period of 14 days. The water quality was adjusted for PH (7.0-7.5), dissolved oxygen $(6.5-7.5 \mathrm{mg} / \mathrm{l})$ and water temperature ranged from $25-27^{\circ} \mathrm{C}$.

Determination of $\mathbf{L C}_{\mathbf{5 0}}$.

Standard of stock solutions of $\mathrm{HgCl}_{2}$ with the molecular weight (325.29) was $1000 \mathrm{mg} / \mathrm{l}$. The working solution was freshly prepared by diluting mercuric chloride according to the level of required doses used. These doses were $0.1,0.2,0.3,0.4,0.5$, $0.6,0.7$ and $0.8 \mathrm{mg} / \mathrm{l}$ of mercuric chloride were applied as follow and replicated:

The first glass aquarium was used as control without any treatment and used as control.

The second glass aquarium, the lethal dose used was $0.1 \mathrm{mg} / \mathrm{l}$ of mercuric chloride. 
The third glass aquarium, the lethal dose used was $0.2 \mathrm{mg} / \mathrm{l}$ of mercuric chloride.

The fourth and fifth glass aquariums, the lethal dose used were 0.3 and $0.4 \mathrm{mg} / \mathrm{l}$ of mercuric chloride respectively.

The sixth and seven glass aquariums, the lethal dose used were 0.5 and $0.6 \mathrm{mg} / \mathrm{l}$ of mercuric chloride respectively.

The eighth glass aquarium, the lethal dose used was $0.8 \mathrm{mg} / \mathrm{l}$ of mercuric chloride.

The total number of fish in each glass aquarium was 12 fish. The experiment of $\mathrm{LC}_{50}$ was extended for 4 days (about 96 hours) after treatment.

Based on the 96 hours of $\mathrm{LC}_{50}$ values, four groups of tilapia fish were then exposed to four sub-lethal concentration of $\mathrm{HgCl}_{2}$. Four glass aquaria were used for this purpose. Each glass aquarium containing 601 . of de-chlorinated water and gently aerated. The number of fish in each glass aquarium was 12 fish in addition to the control group. The experiment extended for 60 days and the doses used were applied as follow:

The first glass aquarium, the dose used was $0.02 \mathrm{mg} / \mathrm{l}$ of mercuric chloride.

The second glass aquarium, the dose used was $0.04 \mathrm{mg} / \mathrm{l}$ of mercuric chloride.

The third glass aquarium, the dose used was $0.06 \mathrm{mg} / \mathrm{l}$ of mercuric chloride.

The fourth glass aquarium the dose used was $0.08 \mathrm{mg} / \mathrm{l}$ of mercuric chloride.

The fifth glass aquarium was used as a control without any treatment.

About half of the water in each aquarium was renewed every 2 days and the concentrated $\mathrm{HgCl}_{2}$ in each aquarium was adjusted according to required dose. Animals were fed with commercial fish food with $25 \%$ protein. The experiment was replicated three times. Addition of selenium compounds (Sodium Selenite, $\mathrm{Na}_{2} \mathrm{SeO}_{3}$ ) in the concentration of 1 and $2 \mathrm{mg}$ of selenium mixed with $1 \mathrm{~kg}$ of fish food respectively to the toxic effect of $\mathrm{HgCl}_{2}$ for a period of 20 days for fish that exposed to sub-lethal concentration of $\mathrm{HgCl}_{2}(0.1 \mathrm{mg} / \mathrm{l})$.

\section{Sample collection:}

Samples were collected after 60 days of treatment. The mortality rates were recorded during the period of experimental study. The mortality rate was calculated according the following equation:

Mortality rate $=$ total number of mortality fish /total number of fish x100

\section{Haematological Parameters:}

The blood from control and treated fish from each treatment was obtained in eppendorf tube containing EDTA anticoagulants according to MgBenka et al., (2003). These treated and control blood samples were used to estimate the haematological parameters of different types of blood cells.

The total red blood cells were counted using Neubaux haemocytometer (Shah and Altindag, 2004). The total number of Red blood cells (RBCs) were recorded as $10^{6} \mathrm{~mm}^{2}$ (Wintrobe, 1967).

The total number of white blood cells (WBCs) was reported as $\mathrm{mm}^{3} \times 10^{3}$ according to (Wintrobe,1967).

Estimation of hemoglobin $(\mathrm{Hb})$ was determined with hemoglobin test kits (DIAGNOVA, Ranbaxy,India) using Cyanmethemoglobin method.

\section{Histopathological Observation:}

Parts of gills and liver tissue were removed and preserved in Bouin's fixation for about 24 hours, after that the tissues were processed, sectioned at 6 microns in thickness and then stained by using haematoxylin and eosin, then examined as usual manner under stereo microscope. 


\section{Statistical Analysis:}

One-way analysis of variance (ANOVA) was used to determine the effect of the different concentrations of $\mathrm{HgCl}_{2}$ on haematological parameters (WBCs, $\mathrm{RBC}$, $\mathrm{Hb}, \mathrm{Ht}, \mathrm{MCV}, \mathrm{MCH}$, and MCHC), The statistical analyses were carried out using the Statistical (SPSS version 20). P-value of $<0.05$ was considered significant.

\section{RESULTS}

$\mathrm{LC}_{50}$ value of mercuric chloride for $O$. niloticus was $0.3 \mathrm{mg} / \mathrm{l}$ following probit analysis method described by Finney (1971). In determination of $\mathrm{LC}_{50}$ of $\mathrm{Hg}$ for a period of 96 hours, 6 out of 12 fish were died after $96 \mathrm{hr}$ of treatment. The mortality rate reached $50 \%$, however, at high concentration of $\mathrm{Hg}$ doses from $0.4 \mathrm{mg} / \mathrm{l}$ reaching to $0.8 \mathrm{mg} / \mathrm{l}$, the mortality rate increased and ranged from 60 to $100 \%$ at 96 $\mathrm{hr}$ (table 1). So, sub-lethal doses was estimated under this doses starting from 0.02 to $0.08 \mathrm{mg} / \mathrm{l}$ of $\mathrm{Hg}$.

Table 1: Mortality rate of different doses of $\mathrm{HgCl}_{2}$ (mg/l) for of O. niloticus.

\begin{tabular}{lllllllll}
\hline \multicolumn{1}{c}{ Parameters } & \multicolumn{7}{c}{ concentrations of $\mathbf{H g C l}_{\mathbf{2}}(\mathbf{m g} / \mathbf{l})$} \\
\hline Time (hr) & 30 & 35 & 45 & 50 & 60 & 70 & 80 & 96 \\
doses of $\mathbf{H g C l}_{\mathbf{2}}(\mathbf{m g} / \mathbf{l})$ & 0.1 & 0.2 & 0.3 & 0.4 & 0.5 & 0.6 & 0.7 & 0.8 \\
Mortality rate \% & 30 & 40 & 50 & 60 & 70 & 75 & 90 & 100 \\
\hline
\end{tabular}

\section{Erythrocyte cells count:}

The erythrocyte count of the control fish showed a mean value of $1.56 \times 10^{6}$. The fish exposed to sub-lethal dose of mercuric chloride showed significant decrease in the red blood cells mean values as $\left(1.5,1.3,1.06\right.$ and $\left.1.0 \times 10^{6}\right)$ after two months of treatment.

\section{Total white blood cells count:}

The results indicated that the total white blood cells after one and two months of treatment showed significant increases $(p<0.05)$ as $\left(8.0,12.27,13.0\right.$ and $\left.14.0 \times 10^{3}\right)$ when compared with the control value $\left(7.16 \times 10^{3}\right)$.

\section{Hemoglobin content:}

The mean value of hemoglobin content of the control fish was $72.3 \mathrm{~g} / \mathrm{dl}$. Fish exposed to the sub-lethal concentrations of mercuric chloride showed that the mean values of $\mathrm{Hb}$ were $64.5,48.25,43.0$ and $34.66 \mathrm{~g} / \mathrm{dl}$ under exposure of $0.02,0.04,0.06$ and $0.08 \mathrm{ppm}$ doses, respectively. These values showed a significance decrease as compared to the control $(\mathrm{P}<0.05)$ as shown in Table (2).

Table 2: Effect of $\mathrm{HgCl}_{2}$ in sub-lethal doses on haematological parameters after two months of treatment on $O$. niloticus.

\begin{tabular}{|c|c|c|c|c|c|}
\hline \multirow[t]{2}{*}{ Variables } & \multirow[t]{2}{*}{ control } & \multicolumn{4}{|c|}{ Hg dose (mg/l) } \\
\hline & & 0.02 & 0.04 & 0.06 & 0.08 \\
\hline WBC $\left(10^{3} / \mathrm{mL}\right)$ & $7.16 \pm 0.05^{\mathrm{e}}$ & $8 \pm 0.18^{\mathrm{d}}$ & $12.27 \pm 0.27^{\mathrm{c}}$ & $13 \pm 0.17^{b}$ & $14 \pm 0.35^{\mathrm{a}}$ \\
\hline RBC $\left(10^{6} / \mathrm{mL}\right)$ & $1.56 \pm 0.10^{\mathrm{a}}$ & $1.5 \pm 0.03^{\mathrm{a}}$ & $1.3 \pm 0.04^{\mathrm{b}}$ & $1.06 \pm 0.05^{\mathrm{c}}$ & $1 \pm 0.06^{\mathrm{c}}$ \\
\hline Hb (g/dL) & $72.3 \pm 0.23^{\mathrm{a}}$ & $64.5 \pm 0.35^{\mathrm{b}}$ & $48.25 \pm 0.35^{\mathrm{c}}$ & $43 \pm 0.46^{\mathrm{d}}$ & $34.66 \pm 0.14^{\mathrm{e}}$ \\
\hline Ht (\%) & $38.25 \pm 0.18^{\mathrm{a}}$ & $34.16 \pm 0.16^{\mathrm{b}}$ & $26.5 \pm 0.23^{c}$ & $22.8 \pm 0.07^{\mathrm{d}}$ & $22 \pm 0.48^{\mathrm{d}}$ \\
\hline MCV (Fi) & $140.7 \pm 1.04^{\mathrm{a}}$ & $135 \pm 0.69^{b}$ & $119 \pm 0.98^{c}$ & $121 \pm 0.69^{c}$ & $120.66 \pm 0.67^{c}$ \\
\hline MCH (Pg) & $27.83 \pm 0.87^{\mathrm{a}}$ & $26.16 \pm 0.16^{\mathrm{a}}$ & $23 \pm 0.64^{b}$ & $22 \pm 0.46 b^{c}$ & $21 \pm 0.64^{\mathrm{c}}$ \\
\hline MCHC (g/dL) & $37 \pm 0.64^{\mathrm{a}}$ & $31 \pm 0.81^{\mathrm{b}}$ & $25.2 \pm 0.75^{\mathrm{c}}$ & $23.5 \pm 0.80^{c}$ & $23.16 \pm 0.21^{\mathrm{c}}$ \\
\hline
\end{tabular}

Different letters = significance difference occurred between the sample treated with selenium and the others without treated $(\mathbf{P}<0.05)$.

\section{Effect of Selenium on fish-treated with $\mathrm{HgCl}_{2}$ :}

The effect of selenium (1.0 and $2.0 \mathrm{mg} / \mathrm{kg}$ fish food) on the fish exposed to lethal dose of $\mathrm{HgCl}_{2}(0.1 \mathrm{mg} / \mathrm{l})$ for a period of 20 days of treatment were studied. In 
fish treated with $\mathrm{HgCl}_{2}$, the white blood cells count was $11.4 \times 10^{3} / \mathrm{ml}$, the Red blood cells count was $1.1 \times 10^{6} / \mathrm{ml}$, hemoglobin value was $34.66 \mathrm{~g} / \mathrm{dl}$. After treatment with selenium which mixed with fish food to detoxify the toxin impact for a period 20 days of treatment, Red blood cells and $\mathrm{Hb}$ were increased, however the white blood cells were decreased as shown in Table (3). Moreover, the blood indices were increased after treatment with selenium.

Table 3: Effect of $\mathrm{HgCl}_{2}$ in high doses $(0.1 \mathrm{mg} / \mathrm{l})$ on haematological parameters and treatment with selenium for 20 days of treatment on $O$. niloticus.

\begin{tabular}{lccc}
\hline \multicolumn{1}{c}{ Variables } & Hg $(\mathbf{0 . 1} \mathbf{~ m g} / \mathbf{l})$ & \multicolumn{2}{c}{ Selenium } \\
\cline { 3 - 4 } & & $1 \mathrm{mg} / \mathrm{kg}$ fish food & $2 \mathrm{mg} / \mathrm{kg}$ fish food \\
\hline WBC (10 $\mathbf{3} / \mathbf{m L})$ & $11.4 \pm 0.16^{\mathrm{a}}$ & $6.5 \pm 0.07^{\mathrm{c}}$ & $7.03 \pm 0.09^{\mathrm{b}}$ \\
RBC $(\mathbf{1 0} / \mathbf{m L})$ & $1.1 \pm 0.07^{\mathrm{c}}$ & $1.5 \pm 0.05^{\mathrm{b}}$ & $1.8 \pm 0.06^{\mathrm{a}}$ \\
Hb (g/dL) & $34.66 \pm 0.39^{\mathrm{c}}$ & $52 \pm 0.69^{\mathrm{b}}$ & $60.33 \pm 0.27^{\mathrm{a}}$ \\
Ht $(\boldsymbol{\%})$ & $27.33 \pm 0.13^{\mathrm{c}}$ & $30 \pm 1.27^{\mathrm{b}}$ & $34.16 \pm 0.17^{\mathrm{a}}$ \\
MCV (Fi) & $108.5 \pm 0.35^{\mathrm{c}}$ & $148 \pm 0.06^{\mathrm{b}}$ & $150 \pm 0.92^{\mathrm{a}}$ \\
MCH (Pg) & $35 \pm 0.52^{\mathrm{b}}$ & $42.33 \pm 0.25^{\mathrm{a}}$ & $42.66 \pm 0.76^{\mathrm{a}}$ \\
MCHC (g/dL) & $26 \pm 0.46^{\mathrm{b}}$ & $39.66 \pm 0.32^{\mathrm{a}}$ & $38.33 \pm 0.21^{\mathrm{c}}$ \\
\hline Different letters = significant difference $(\mathbf{P}<\mathbf{0 . 0 5})$.
\end{tabular}

\section{Heavy metal (Hg) and fish behavior:}

The control fish was observed in normal swimming state. The fish exposed to heavy metal $(0.1 \mathrm{mg} / \mathrm{l} \mathrm{HgCl} 2)$ was observed in stress state and hypersensitivity. The movement and swimming of fish were observed in the abnormal condition. The morphological appearance showed that the most scales over skin were removed and the fish could not be protected from fungi and bacteria. The color of fish changed from normal condition to pale white color and the skin covered with much amount of mucus. The fish lost its ability to eat and decreased in body weight, and then died.

\section{Histopathology of treated liver:}

The liver of the control Oreochromic niloticus exhibited normal structure. The hepatocytes contain homogenous cytoplasm and centrally located nuclei, small blood sinusoids distributed between the hepatocyte and its function to collect the aggregated blood from these cells to pour into the central vein. The hepatopancrease was also observed and contained in the center vacuole red blood cells. No lesions occurred in the liver of the control fish (Fig. 1A). The slight alternations occurred inside the hepatocyte of the liver of treated fish with doses ranged between 0.02 to $0.04 \mathrm{mg} / \mathrm{l} \mathrm{of}$ $\mathrm{HgCl}_{2}$ for a period 60 days of treatment. The main alteration occurred either in the cytoplasm of hepatic cells or inside the nucleus. The cytoplasm appeared in abnormal shape and some of them appeared as vacuole. Small blood vessels were slightly dilated and contained red blood cells (Fig. 1B). Abnormalities were observed in the treated liver with $0.04 \mathrm{mg} / \mathrm{l}$ of $\mathrm{HgCl}_{2}$ for a period of 60 days. The main alteration occurred in the cytoplasm and the nucleus. The cytoplasmes were hypertrophied and sever degradation of liver parenchyma and the most nuclei were disintegrated (Fig. 1C). The treated liver, Oreochromic niloticus with $0.06 \mathrm{mg} / \mathrm{l} \mathrm{HgCl}{ }_{2}$ for 60 days showed that the hepatocytes were more hypertrophied and some nuclei become necrosis. The blood vessels appeared between the hepatocytes were dilated and branched vessels contained red blood cells (Fig. 1D). The main alteration occurred in the liver of Oreochromic niloticus after 60 days of treatment with $0.08 \mathrm{mg} / 1 \mathrm{HgCl}_{2}$. The hepatocyte were more hypertrophied and most of these cells appeared as vacuoles without nuclei. The blood sinusoid was congestion (Fig. 2A). The treated liver of Oreochromic niloticus with acute dose $0.1 \mathrm{mg} / \mathrm{l}$ of $\mathrm{HgCl}_{2}$ for 20 days showed the main alteration occurred in 
cytoplasm and nucleus. The cytoplasm were disorganized and nuclei showed necrosis Fig. 2B).

The treated liver with $0.1 \mathrm{mg} / \mathrm{l} \mathrm{HgCl}_{2}$ and $1.0 \mathrm{mg}$ selenium $\left(\mathrm{Na}_{2} \mathrm{SeO}_{3}\right) / \mathrm{kg}$ of fish food which used as recovery for 20 days, the hepatocyte appeared with few lesions and the nuclei located towards the center of cells. The parenchyma of liver appeared similar to that observed in the normal state (Fig. 2C).

\section{Histopathology of gills}

The gills in Oreochromis niloticus consists of filaments and secondary lamellae. In control fish, the gill had a normal structure. There is no lesions occurred in both of primary and secondary lamellae (Fig-3A). Gills of Oreochromis niloticus treated with $0.04 \mathrm{mg} / \mathrm{l} \mathrm{of} \mathrm{HgCl}_{2}$ for a period of 60 days showed that the secondary lamellae were shorted and some of these lamellae were lifting up and fused at the base of filaments (Fig. 3B). Moreover these were alternation occurred in the treated gills of Oreochromis niloticus with $0.06 \mathrm{mg} / \mathrm{l}$ of $\mathrm{HgCl}_{2}$ for a period of 60 days. The lesions in both secondary and primary lamella were observed. The primary lamellae increased in thickness and secondary lamellae become more shortening. The mucous cells scattered along the epithelial of the secondary lamellae (Fig. 3C)

The treated gills with $0.08 \mathrm{mg} / \mathrm{l}$ of $\mathrm{HgCl}_{2}$ for 60 days showed that the secondary lamellae were fused and the cells of the primary lamellae were more proliferated (Fig. 3D).

More modification occurred showed the treaded gills with acute of $0.1 \mathrm{mg} / \mathrm{l}$ $\mathrm{HgCl}_{2}$ for a period of 20 days. The secondary lamellae in disorganization and fusion in lamellae in the most portion of filament. The hemorrhage was also observed at the base of filament (Fig. 4A). The results declared that the treated gills with $0.1 \mathrm{mg} / \mathrm{l} \mathrm{of}$ $\mathrm{HgCl}_{2}$ and selenium $\left(\mathrm{Na}_{2} \mathrm{SeO}_{3}\right)$ at doses of $1.0 \mathrm{mg} / \mathrm{kg}$ of fish food for a period of 20 days of treatment appeared similar to the gills of the control fish. The primary and secondary lamellae appeared with slight lesions.

\section{DISCUSSION}

Heavy metals such as $(\mathrm{Cr}, \mathrm{Pb}, \mathrm{Zn}, \mathrm{Cu}, \mathrm{Ni}, \mathrm{Cd}$ and $\mathrm{As}$ are the most important environmental problems today (Nariagu and Pacyma, 1988; Witeska, 2003). Mercuric chloride $\left(\mathrm{HgCl}_{2}\right)$ is one of the most important heavy metal representing the greatest hazards to human consumer of fish. So, the analysis of changes in some hematological and biochemical blood indices remain as variable tools in determining the effects of sub-lethal concentrations of pollutants. In the present study a decrease in the erythrocyte count indicated the worsening of an organism state and finally, the anemia occurred. Similar findings were observed in Puntius conchonius after mercury exposure for weeks (Gill and Pant, 1987). In this respect, Gill and Epple (1993) have attributed anemia to impaired erythrothyte due to the effect of heavy metals on hematopoietic centers (kidney and spleen). In our opinion, the deficiency in red blood cells to inability of blood to carry sufficient oxygen and distributed it to various organs in body fish. Similar observation were obtained by Shah and Altindag (2004) who stated that a number of hematological indices such as hematocrit, hemoglobin and red blood cells are used to assess the functional status of oxygen carrying capacity in the blood stream and used as indicator of metal pollution in the aquatic environment. In the present study, the percentage value of hemoglobin was markedly decreased after the fish exposed with the high doses of $\mathrm{HgCl}_{2}(0.08$ $0.1 \mathrm{mg} / \mathrm{l})$. These results are similar to the data obtained by Gill and Epple (1993). McKim et al., (1979) reported that mercury accumulated in fish blood. Similar results 
were obtained in previous study by Sastry and Kamana sharma (1980) showing that hemoglobin and hematocrit were declined as Channa punctatus exposed to mercury.

It is known that the immune system considers as the first defense line against the bacteria, virus and pollutants. Therefore total white blood cells play an important role in defense mechanism In the present study. The total white cell in fish that exposed to high level dose of $\mathrm{HgCl}_{2}$ was increased in compared to the control fish. The exposed fish with high level does of $\mathrm{HgCl}_{2}(0.1 \mathrm{mg} / \mathrm{l})$ and Selenium $\left(\mathrm{Na}_{2} \mathrm{SeO}_{3}\right)$ of ( 1.0 and $2.0 \mathrm{mg} / \mathrm{kg}$ ) for a period of 20 days of treatment improved Red and white blood cells count and blood indices. It appears that Selenium (Se) is a necessary as micronutrient to ameliorate the effect of $\mathrm{Hg}$ in several organisms as reported by Truong et al., (2014).

Selenium interacted with $\mathrm{Hg}$ showed protective effect of toxicity as described by Yang et al., (2008). The present results showed that erythrothyte, hemoglobin, and hematocrit value increased, however, white blood cells decreased to a normal value.

In the present study, the behavior of the treated fish was observed showing hypersensitivity. The swimming fish were observed in the abnormal state and the color change from natural normal color to white color (Srivastava, 1982). This change in the behavior of fish according to previous studies and the present study were attributed to hormonal imbalance caused by the toxic effect of $\mathrm{HgCl}_{2}$.

The effect of $\mathrm{HgCl}_{2}$ on the liver cells was dependent on the duration of exposure and its concentration. As observed in the present study, the treated fish with $\mathrm{HgCl}_{2}$ doses $(0.02-0.06 \mathrm{mg} / \mathrm{l})$ revealed alterations as observed in the nuclei and cytoplasm of the hepatocyte. In this respect, cytoplasmic vacuolation was observed in hepatocyte and similar results were described by Fanta et al., (2003) and EL-Greisy et al., (2016) on Oreochromis nilotticus and EL-Greisy and EL-gamal (2015) on Cyprinus carpio.

Another vital organ in the fish is gills which play on important part in respiratory, osmoregulation and excretion function, furthermore, the gills are regarded as the primary target of the contamination (Ahmed et al., 2014). As observed in the present study, the normal structure of gill consists of primary lamellae, secondary lamellae that have pillar cells which separate the walls that composed of squamous epithelium. The fish gills treated with sub-lethal concentration $(0.02-0.06 \mathrm{mg} / \mathrm{l})$ have showed slight damage after 30 days of treatment. These results are inconsistent with EL-Greisy et al., (2016). In the fish gill treated with doses level ranged from 0.08 to $0.1 \mathrm{mg} / \mathrm{l}$, a damage occurred in the epithelial covering the secondary lamella and more fusions occurred in secondary lamellae with hemorrhage of blood collected at the base of the filament. The damage in the epithelial membrane is primary reaction, whereas mercury element picks up charge which is similar to many of the ions charges $\mathrm{Ca}^{+2}$ and $\mathrm{Mg}^{+2}$ and competing on the union and transit through the chloride cells (Change et al., 2003; Wu et al., 2008). In the present study, the tissues gills and liver treated which $0.1 \mathrm{mg} / \mathrm{l} \mathrm{of} \mathrm{HgCl}_{2}$ and the Selenium $\left(\mathrm{NaSeO}_{3}\right)$ at dose of $1.0 \mathrm{mg} / \mathrm{kg}$ of fish food for a period of 30 days of treatment showed recovery of both tissues were observed. Truong et al., (2014) stated that Selenium $\left(\mathrm{NaSeO}_{3}\right)$ is necessary micronutrient which interact with $\mathrm{Hg}$ in several organisms.

\section{CONCLUSION}

Based on this study, it can be concluded that the heavy metal (mercury) is a dangerous to the Nile Tilabia (O. niloticus). The present study detected a method 
that can be beneficial for the removal of mercuric chloride toxicity, that by using selenium $\left(\mathrm{NaSeO}_{3}\right)$. The present study give explanation for the toxic effect of $\mathrm{HgCl}_{2}$ on liver and gill tissues as well as the hematological parameters after 60 days of exposure. These effects were ameliorated after addition of selenium (1.0-2.0 mg/kg fish food) for a period of 20 days.

\section{REFERENCES}

Ahmed, Q.; Yousuf, f. sarfraz, M.A. (2014). Seasonal elemental variation of Fe, Mn, $\mathrm{Cu}$ and $\mathrm{Zn}$ and conservational management of rastrelliger kanagurta fish from Karachi fish harbor, Pakistan, journal of food, agriculture and environment $12(3 * 4): 405-414$.

Asefi, M.; Zamani-Ahmadmahmoodi, R. (2015). Mercury concentrations and health risk assessment for twofish species, Barbus grypusandBarbus luteus, from the Maroon River, Khuzestan province, Iran. Environ Monit Assess:187.

ATSDR. (Agency for Toxic Substance and Disease Registry) (2003). Toxicological profile for mercury. Atlanta, GA, USA: US Department of Health and Humans Services, Public Health Human Services, Centers for Diseases Control.

Beheary, M.S.; Abu-Almaaty, A.H. and El-matary, F.A. (2015). Genetic Polymorphism and Heavy Metals in Catfish Clarias Gariepinus from Different Sites as a Result of Environmental Contamination. Adv. Environ. Biol.; 9(18): 20-32.

Beheary, M.S. and El-matary, F.A (2018). Bioaccumulation of Heavy Metals and Implications Associated with Consumption of the Thinlip Mullet (Liza Ramada) Collected from Sites of Varying Salinity. Asian Journal of Fisheries and Aquatic Research, 2(2): 1-15, 2018; Article no.AJFAR.44449.

Bjorklund, G.; Aaseth, J.; Ajsuvakova, O.P.; Nikonorov, A.A.; Skalny, A.V.; Skalnaya, M.G.; Tinkov, A.A. (2017). Molecular interaction between mercury and selenium in neurotoxicity. Coord. Chem. Rev. 332, 30-37.

Chang, I.C.; Wei,Y.; Chou, F. and Hwang, p. (2003). Stimulation of Cl - uptake and morphological changes in gill mitochondria rich cells in fresh water tilapia (oreochromis mossambiais ) physiological and biochemical zoology 76:544552.

Chapman, L. and Chan, H.M. (2000). The influence of nutrition on methylmercury intoxication. Environ Health Perspect;108:29-56.

Clarkson, T. (1998). Methylmercury and fish consumption: weighing the risks. Can Med Assoc J;158:1465-6.

El- Greisy, Z. A.; Elgamal, A. E. and Ahmed, N.A. (2016). Effect of prolonged ammonia toxicity on fertilized eggs, hatchability and size of newly hatched larvae of Nile tilapia Oreochromis Niloticus. Egypt. J. Aquatic Res., 42(2):

El- Greisy, Z.A. and Elgamal, A. E. (2015). Experimental studies on the effect of cadmium chloride, zinc acetate, their mixture and the mitigation with vitamin $\mathrm{C}$ supplementation on hatchability, size and quality of newly hatched larvae of common carp, Cyprinids Carpio. Egypt. J. Aquatic Res. 41(2)

Fanta, E.; Rios, F.S.; Romao, S.; Vianna, A.C.C. and Freibrger, S. (2003). Histopathology of fish, Corydoras Paleatus Histopathology of fish, corydoras paleatus contaminated with sub-lethal level of organophosphrus in water and food. Ecotoxicol Environment Saf. 54,119-130.

Finney, D.J. (1971). Probit Analysis Cambridge University Press, New York, New Delhi. p.337. 
GAFRD. (2001). General Authority for Fish Resources Development: Report on Fish Production, Cairo, Egypt.

Gill, T.S. and Epple, A. (1993). Stress related changes in the hematological profile of the American ecl, Anguilla Rostrata. Ecotoxical. Environ. Saf. 25; 227-235.

Gill, T.S. and pant, J.C. (1987). Hematological and pathological effects of chromium toxicities in fresh water fish, Barbus comchonius ham. Water, Air soil pollut. 35:421-450.

Groth, I.I.I.E. (2010). Ranking the contributions of commercial fish and shellfish varieties to mercury exposure in the United States: implications for risk communication. Environ Res;110:226-36.

Ikingura, J.R. and Akagi, H. (2003). Total mercury and methyl mercury levels in fish from hydroelectric reservoirs in Tanzania. Sci Total Environ;304:355-68.

IPCS. (International Program on Chemical Safety) (2003). Elemental mercury and inorganic mercury compounds. Geneva: World Health Organization.

Jones, H.J.; Swadling, K.M.; Tracey, S.R. and Macleod, C.K. (2013). Long-term trends of $\mathrm{Hg}$ uptake in resident fish from a polluted estuary. Mar Pollut Bull;73:263-72.

Kruzikova, K.; Randak, T.; Kensova, R.; Kroupova, H.; Leontovycova, D. and Svobodova, Z., (2008). Mercury and methylmercury concentrations in muscle tissue of fish caught in major rivers of the Czech Republic. Acta Vet Brno., 77:637-43.

Lemire, M.; Fillion, M.; Frenette, B.; Mayer, A.; Philibert, A.; Passos, C.J.S.; Guimaraes, J.R.D;, Barbosa, F. and Mergler, D. (2010). Selenium and mercury in the Brazilian Amazon: opposing influences on age-related cataracts. Environ. Health Perspect. 118: 1584-1589.

Mckim, J.M. and Olson,G.F.et al. (1979). longterm effects of methyl mercuric chloride on three generations of brook trout (salualinus fontinalis) Toxicity, accumulation, distribution and elimination J.fish.Res.Bd. Canada 332726.

Mgbenka, et al. (2003). Effect of Gammalin 20 (Lindane) on deferential white blood cells counts of the African Catfish, Clarias Albopunctata. Bull of Environmental Contamination Toxicol.,71:248-254.

Moniruzzaman, M.; Lee, J-Ho.; Lee, J-Hy.; Won, S.; Damusaru, J. H. and Bai, S. C. (2017). Interactive effect of dietary vitamin $\mathrm{E}$ and inorganic mercury on growth performance and bioaccumulation of mercury in juvenile olive flounder ,Paralichthys olivaceus treated with mercuric chloride. Animal Nutrition 3: 276-283. http://dx.doi.org/10.1016/j.aninu.2017.07.001.

Moon, H.B.; Kim, S.J.; Park, H.; Jung, Y.S.; Lee, S. and Kim, Y.H., et al. (2011). Exposure assessment for methyl and total mercury from seafood consumption in Korea, 2005e2008. J Environ Monit;13:2400-5.

Nijmi, A.J. and Kissoon, G.P. (1994). Evaluation of the critical body burden concept based on inorganic and organic mercury toxicity to rainbow trout (Oncorhynchus mykiss). Arch Environ Contamin Toxicol, 26:169-78.

Nriagu, J.O. and pacyna,J.M. (1988). Quantitative assessment of world. Wide contamination of air, water and soils by trace metals. Nature, 333:134-139.

Penglase, S.; Hamre, K. and Ellingsen, S., (2014). Selenium and Mercury have a synergistic negative effect onfish reproduction. Aquat. Toxicol., 149:16-24.

Pieniak, Z.; Verbeke, W. and Scholderer, J. (2010). Health-related beliefs and consumer knowledge as determinants of fish consumption. J Hum Nutr Diet, 23:480-8. 
Sastry, K.V. and sharma, K. (1980). Mercury induced haematological and biochemical anomalies in Ophiocephalus ( Chamm Punctatus).Toxicology letters., 5: 245-249.

Shah, S.L. and Altinday, A. (2004). Hematological pardmeters of tench (Tinca tincal) after acute and chronic exposure to lethal and sublethal mercury treatments. Bull. Environ. Contam. Toxical. 73:911-918.

Strivastava, D.K. (1982). Comparative effects off copper, cadmium and mercuric chloride on tissue glycogen on the catfish, Heteropneustes fossils (Bloch). Toxical. Let., 11:135-135.

Swanson, D.; Block, R. and Mousa, S.A., (2012). Omega-3 fatty acids EPA and DHA: health benefits throughout life. Adv Nutr, 3:1-7.

Truong, H.Y.T.; Chen, Y.W.; Saleh, M.; Nehzati, S.; George, G.N.; Pickering, I.J. and Belzile, N., (2014). Proteomics of Desulfovibrio desulfuricansand X-ray absorption spectroscopy to investigate mercury methylation in the presence of selenium. Metallomics, 6: 465-475.

Vieira, C.; Morais, S.; Ramos, S.; Delerue-Matos, C. and Oliveira, M.B.P.P. (2011). Mercury, cadmium, lead and arsenic levels in 3 pelagic fish species from the Atlantic Ocean: intra and inter-specific variability and human health risks for consumption. Food Chem Toxicol, 49: 923-32.

Wang, W-X.; Onsanit, S. and Dang, F. (2012). Dietary bioavailability of cadmium, inorganic mercury, and zinc to a marine fish: effects of food composition and type. Aquaculture, 356-357:98-104.

Wang, X. and Wang, W.-X. (2017). Selenium induces the de-methylation of mercury in marine fish, Environmental Pollution, 1-9. http://dx.doi.org/10.1016/j.envpol.2017.09.014.

Wintrobe, M. M. (1967). Clinical Hematology Lea and Febiger Philadelphia(6 ${ }^{\text {th }}$ eds), Library Of Congress, Print USA.

Witeska, M. (2003). The effect of metals pb, cu, cd and $\mathrm{zn}$ on haematological parameters and blood cell morphology of common carp, rozpraw naukowa $\mathrm{nr}$ 72, wydawnictwo akademii podlaskiej siedlce (inpolish)

WU, S.M.; Ding, H.; lin, L. And Lin,Y. (2008). Juvenile tilapia (Oreochromis Niloticus) strive to maintain physiologicall function of liver waterborne copper exposure Archives of Environmental Contamination and Toxicology, 54: 482492.

Wyatt, L.H.; Diringer, S.E.; Rogers, L.A.; Hsu-Kim, H.; Pan, W.K. and Meyer, J.N. (2016). Antagonistic growth effects of mercury and selenium in Caenorhabditis elegans are chemical-species-dependent and do not depend on internal $\mathrm{Hg} / \mathrm{Se}$ ratios. Environ. Sci. Technol., 50, 3256-3264.

Yang, D.Y.; Chen, Y.W.; Gunn, J.M. and Belzile, N. (2008). Selenium and mercury in organisms: interactions and mechanisms. Environ. Rev., 16: 71-92. 

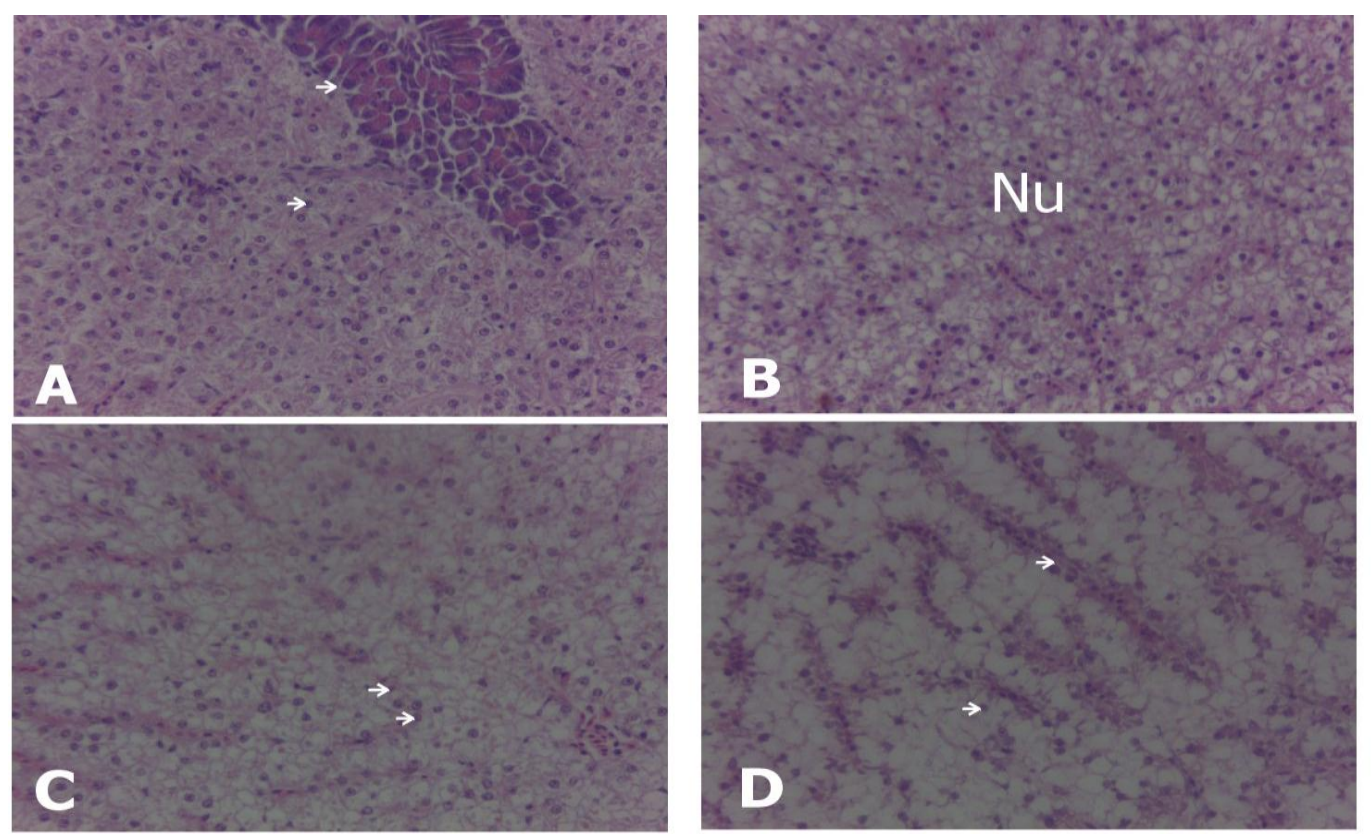

Figure 1. Photomicrograph sections of the control and treated liver of $O$. niloticus

A- control liver of Oreochromis niloticus showing normal structure of liver cells with centrally located nuclei (Arrow head), hepatopancreas contained blood cells was also observed (Arrow).(H\&E,X400).

B- liver of Oreochromis niloticus treated with $0.02 \mathrm{mg} / \mathrm{l}$ of $\mathrm{HgCl}_{2}$ for 60 days showing the hepatocytes with irregular nuclei $(\mathrm{Nu})$, blood sinusoids $(\mathrm{BS})(\mathrm{H} \& \mathrm{E}$, $\mathrm{X} 400)$.

C- liver of Oreochromis niloticus treated with $0.04 \mathrm{mg} / \mathrm{l}$ of $\mathrm{HgCl}_{2}$ for 60 days showing hypertrophied hepatocytes, with degenerated nuclei, sever degradation of liver parenchyma (Arrow) and hepatic portal veim (Arrow heads) (H\&E,Hx400).

D- liver of Oreochromis niloticus treated with $0.06 \mathrm{mg} / \mathrm{l}$ of $\mathrm{HgCl}_{2}$ for 60 days, showing hypertrophied hepatocytes with some necrotized and degenerated nuclei (Arrow), dilated and branched blood vessel containing red blood cells (Arrow head) (H\&E,X400). 


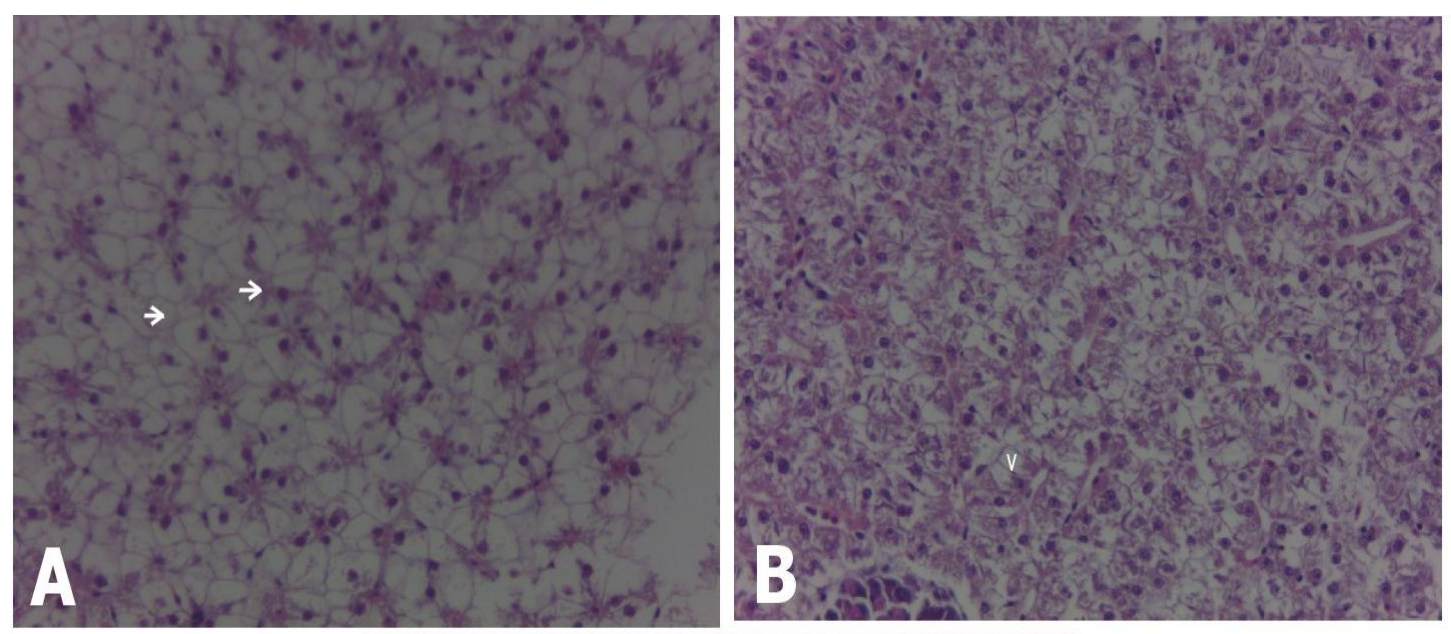

Figure 2

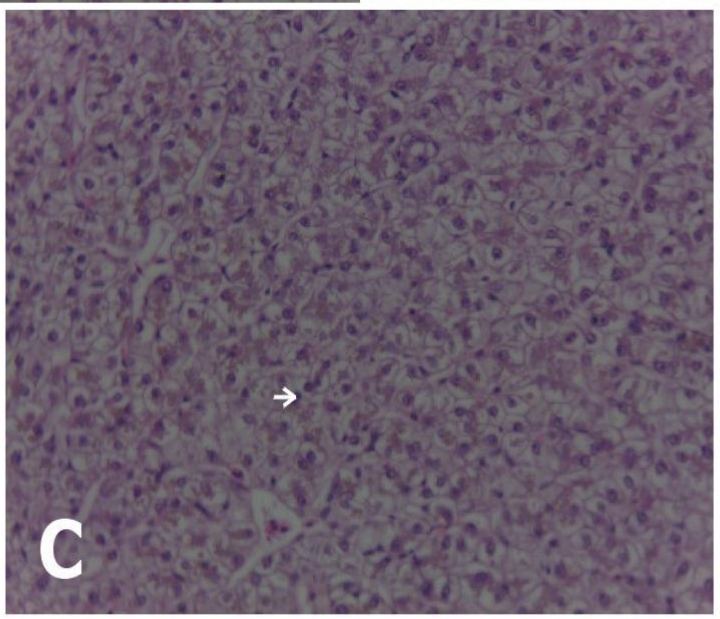

Figure 2. Photomicrograph sections of the treated liver of Oreochromis niloticus (A-C) showing:

A- liver of Oreochromis niloticus treated with $0.08 \mathrm{mg} / \mathrm{l}$ of $\mathrm{HgCl}_{2}$ for 60 days showing the hepatocytes more hypertrophied and most of them devoid from nuclei (Arrow) with the congestion of the blood sinusoids were (Arrow head) (H\&E, X400)

B- liver of Oreochromis niloticus treated with $0.1 \mathrm{mg} / \mathrm{l}$ of $\mathrm{HgCl}_{2}$ showing the hepatocytes were disorganized with necrosis of nuclei (Arrow), vacuoles inside hepatocyte (V) (H\&E, X400)

C- liver of Oreochromis niloticus treated with $0.1 \mathrm{mg} / \mathrm{l}$ of $\mathrm{HgCl}_{2}$ and $1.0 \mathrm{mg}$ selenium $\left(\mathrm{Na}_{2} \mathrm{SeO}_{3}\right) / \mathrm{kg}$ for about 20 days showing slight lesions of hepatocyte (Arrow) and nuclei in the center of cells (Arrow head) (H\&E, X400). 

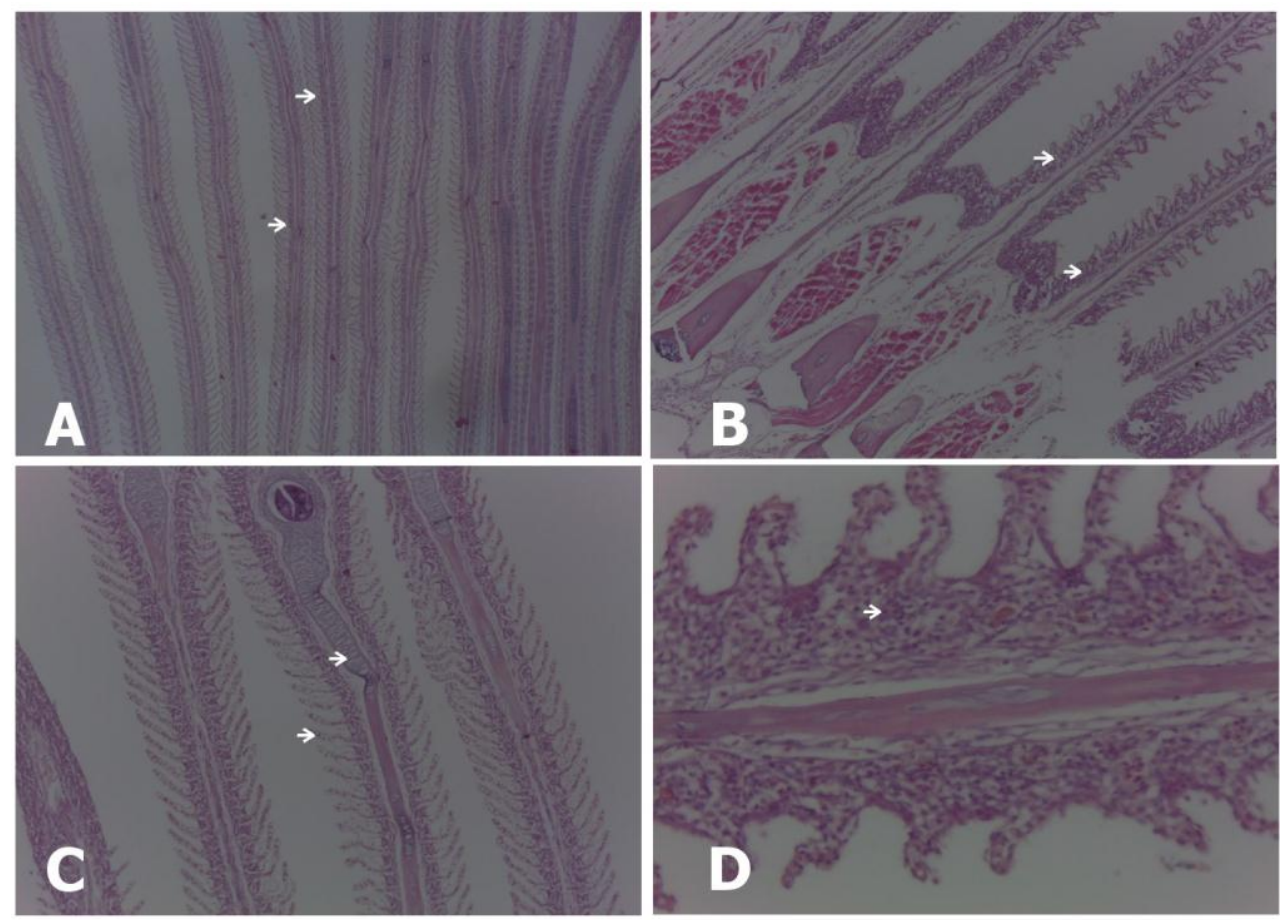

Figure 3. Photomicrograph sections in the gills of $O$. niloticus (A-D) showing:

A- The normal structure of gills in control fish, primary lamellae and secondary lamellae were observed in normal state(Arrow) (H\&E, X100)

B- Gills of Oreochromis niloticus treated with $0.04 \mathrm{mg} / \mathrm{l}$ of $\mathrm{HgCl}_{2}$ for 60 days, showing some secondary lamellae were shorted and some of them were lifting and fused at the base of filaments (Arrow) (H\&E, X400)

C- Gills of Oreochromis niloticus treated with $0.06 \mathrm{mg} / \mathrm{l}$ of $\mathrm{HgCl}_{2}$ for 60 days, showing some secondary lamellae were more shorted (Arrows) and the primary lamellae increased in the thickness (Arrow head), (H\&E, X100)

D- Gills of Oreochromis niloticus treated with $0.08 \mathrm{mg} / \mathrm{l}$ of $\mathrm{HgCl}_{2}$ for 60 days, showing secondary lamellae fused and primary lamellae more proliferated (Arrow) (H\&E, X400).
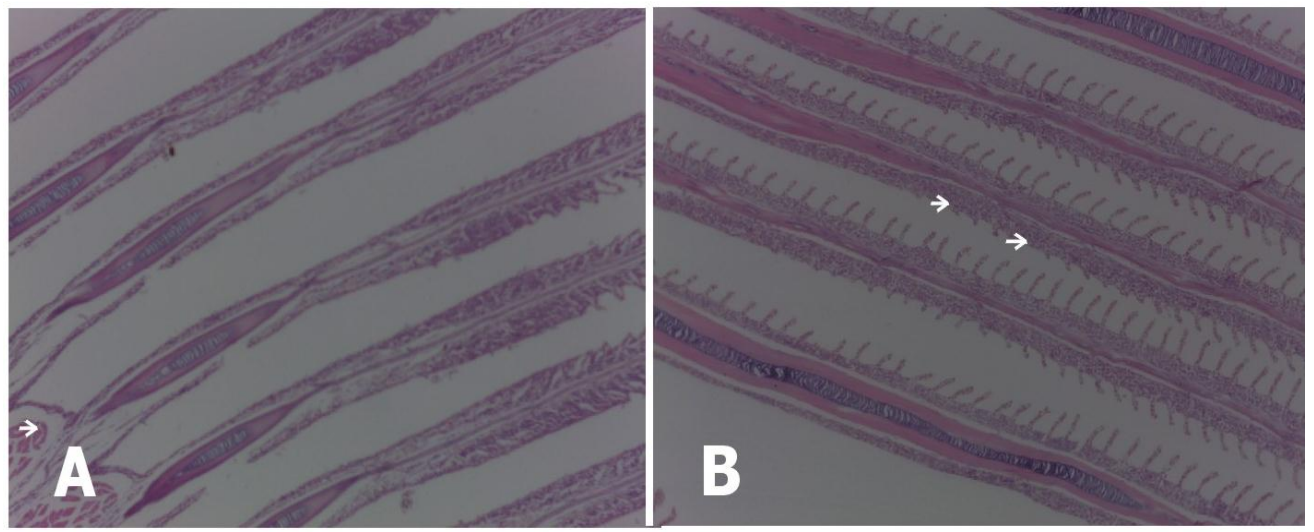

Figure 4. Photomicrograph sections in the gills of O. niloticus (A-B) for 30 days showing:

A-Gills of Oreochromis niloticus treated with $0.1 \mathrm{mg} / \mathrm{l} \mathrm{of} \mathrm{HgCl}_{2}$ showing disorganization and fusion in the secondary lamellae (Arrow), (H\&E, X100).

B-Gills of Oreochromis niloticus treated with $0.1 \mathrm{mg} / \mathrm{l} \mathrm{of} \mathrm{HgCl}_{2}$ and and $1.0 \mathrm{mg}$ selenium $\left(\mathrm{Na}_{2} \mathrm{SeO}_{3}\right) / \mathrm{kg}$ for a period of 20 days showing the gills appeared similar to the gills of the control in both of primary and secondary lamellae (Arrow) (H\&E, x100). 